Article

\title{
Environmental Sustainability and the Hospitality Customer Experience: A Study in Tourist Accommodation
}

\author{
Miguel Ángel Moliner*, Diego Monferrer®, Marta Estrada and Rosa M. Rodríguez \\ Department of Business Administration and Marketing. Jaume I University, 12071 Castellón de la Plana, Spain; \\ dmonferr@uji.es (D.M.); estrada@uji.es (M.E.); artola@uji.es (R.M.R.) \\ * Correspondence: amoliner@uji.es
}

Received: 3 September 2019; Accepted: 23 September 2019; Published: 25 September 2019

check for updates

\begin{abstract}
Academic research on sustainability in the hospitality industry is scarce and fragmented, and requires a general structure to lend coherence to its approach. There is a need for empirical research to fathom the question of environmental sustainability and customer experience in the hospitality industry and to study the interaction between the two concepts. This paper aims to close these gaps by establishing the nature of the relationship between customers' perceptions of the environmental practices in tourism accommodation and their customer experiences and levels of satisfaction. The working hypotheses, based on a review of the literature on environmental sustainability and customer experience in the hospitality industry, are tested in an empirical study of 412 Spanish customers who stayed in various types of tourist accommodation. The main conclusion is that the relationship between environmental sustainability and customer experience in the hospitality industry can be demonstrated. This paper also validates a measurement scale based on the most accepted dimensionality of the construct: cognitive (think), affective (feel), behavioral (act), sensory (sense) and social (relate).
\end{abstract}

Keywords: tourist experience; environmental sustainability; tourist satisfaction; hospitality industry

\section{Introduction}

Currently two of the most relevant terms in tourism at an academic and professional level are environmental sustainability and customer experience. This paper asks how far the hospitality industry's efforts in environmental sustainability influence a more positive tourist experience, and, indirectly, satisfaction. We start from the hypothesis that the environmental sustainability tourists perceive improves their experience, which positively influences satisfaction.

Environmental sustainability is now a major concern for governments and the public at large [1]. This concern has been driven by the undesirable consequences of economic and demographic growth on the consumption of natural resources [2]. The tourism sector is no stranger to this concern for the planet given its significant impact on the natural environment and the consumption of non-renewable resources [3].

Figures from the United Nations World Tourism Organization (UNWTO) show that in 2018 more than 1300 million international tourists generated revenues of just over 1300 billion dollars and around $15 \%$ of global employment. These data place tourism fourth in the list of most important global industries, behind the petroleum, chemistry and automobile industries [4], and illustrate not only the economic and social impacts of tourism but also the environmental impact that such huge movements of people can have on the planet $[5,6]$.

The United Nations defines sustainability as meeting the needs of the present without compromising the ability of future generations to meet their own needs. In the same line the 
UNWTO defines sustainable tourism as that which considers the present and future impact on the economy, society, and the environment, and satisfies the needs of visitors, industry, the environment, and the local community. As can be seen in this definition, the UNWTO conceptualizes sustainability in three dimensions: economic (profit), social (people) and environmental (planet) [2]. In this study we focus on the environmental dimension of sustainability and its impact on the customer experience in tourist accommodation.

According to Niñerola et al [7], "environmental sustainability implies that natural resources should be maintained at a sustainable rate because they are generally non-renewable." Environmental sustainability refers to the balance that must exist between an activity and the environment in which it is developed, where the two interact without detriment to each other [2]. Since the Declaration of The Hague on Tourism in 1989, a large body of environmental protection legislation has been enacted and incorporated into hospitality industry management [8]. In parallel, the hospitality industry is immersed in a process of adapting its business model to a paradigm based on the use of renewable energies, the efficient use of natural resources, and the recycling of waste, with the aim of minimizing its impact on the environment [1-4]. This transformation requires considerable investment of financial resources and the modification of internal procedures [9]. Some authors believe that corporate social responsibility (CSR) practices are an unnecessary use of resources and have a negative impact on profits [9-11], while others argue that a CSR strategy generates customer satisfaction and loyalty and, hence, higher income [9-12]. The question is, therefore, whether customers value the efforts made by the hospitality industry in this direction and whether they have a positive impact on their assessment, and in turn, on the business results.

Hotels are under pressure from their stakeholders, mainly tour operators and customers, to adopt environmental practices that meet their environmental expectations and demands [9]. Travelers increasingly expect to stay in accommodation with a minimal ecological footprint. The hospitality industry increasingly takes this environmental dimension into account as part of its aim to offer positive and satisfactory experiences to its customers, which are transmitted online and offline, to achieve a competitive advantage over its rivals $[9,13,14]$.

According to Jones et al. [1], academic research on sustainability in the hospitality industry is scarce and fragmented, and requires a general structure to lend coherence to its approach. There is a need for empirical research to fathom the question of environmental sustainability and customer experience in the hospitality industry and to study the interaction between the two concepts. This paper aims to close these gaps by establishing the nature of the relationship between customers' perceptions of the environmental practices in tourism accommodation and their customer experiences and levels of satisfaction. To achieve this objective the document is structured in several sections. First, a review of the literature on sustainability and tourist experience in accommodation industry. From this review three hypotheses relating to environmental practices and tourist experiences with satisfaction have been raised. Second, a description of the methodology used to test the hypothesis that includes an empirical study of 412 Spanish customers who stayed in various types of tourist accommodation. From the analysis of the results, some conclusions can be drawn for both academia and managers.

This paper makes four contributions to the hospitality industry literature: a) it establishes a direct causal relationship between environmental sustainability and customer experience; $b$ ) it establishes an indirect relationship between environmental sustainability and customer satisfaction; c) it proposes a customer experience measurement scale; and d) it demonstrates the reflective nature of the customer experience construct.

\section{Theory and Hypotheses}

Although tourism makes a considerable contribution to the economy and employment, it also has a negative impact on the environment through pollution, environmental degradation, damage to biodiversity, generation of waste, and overexploitation of non-renewable resources such as energy and water [3]. All agents involved in the tourism business are now modifying their strategies as a 
result of increasing awareness of the world's environmental problems, and in parallel the interest of tourism researchers has evolved from a vision of sustainability as a way of improving the image of a tourist destination and accommodation, to the current understanding that sustainability is part of the organization, with notable internal and external impacts [7].

The hospitality industry is a major part of the tourist ecosystem. It has an obvious impact on the environment since it accounts for a significant amount of the energy and water consumed and waste generated in tourism regions [3-9]. Jones et al. [1] argue that environmental issues in the hospitality industry should include "climate change and greenhouse gas emissions; water stewardship; waste management and recycling; environmentally responsible sourcing, bio-diversity and protection and preservation of natural resources; the reduction of environmental impact; and the creation of green construction standards for new hotel construction" (p.12). How to manage these aspects is now a priority question due to the increase in environmental awareness across society in general, and among tourists in particular, in recent years $[1,5,15]$ (for a review of studies on environmental sustainability in the hospitality industry see [1]).

Hospitality is defined as what hosts offers their guests [16]. Hospitality covers the guest's experience with the employees and the physical environment, including the facilities, of the accommodation. From the point of view of hospitality, the accommodation provider's objective is to offer the tourist a satisfactory experience [14], and as such, the tourist's experience in the accommodation is now a key aspect for the hospitality industry.

Although the relationship between environmental sustainability and the tourist experience has received little attention in the hospitality industry, some studies do point to a positive relationship between the two. In general, Lemon and Verhoef [17] consider that quality of the service and the environment are antecedents of the customer experience. In the more specific context of the hospitality industry, in a study of US hotel customers, Lee et al. [18] showed that a green image of the hotel promotes a more favorable intention to revisit, to make positive recommendations, and a willingness to pay premium prices. Berezana et al. [8] consider that hotels which implement sustainable practices are more competitive because customers expect to find environmental attributes. Benavides et al. [19] consider that a high level of corporate social responsibility (CSR) in the hospitality industry positively influences customers' attitudes, and as a result, the environmental dimension plays an important role in hotels because it is increasingly linked to the quality of the tourist product. An accommodation provider's environmental practices could therefore be a key factor in obtaining competitive advantage by helping to maintain the appeal of the establishment and attracting new tourists. These arguments lead us to our first hypothesis:

$\mathrm{H}_{1}$ : The customer's perception of the environmental practices in a tourist accommodation establishment positively influences their experience.

The research on the tourist experience in the hospitality industry is scarce (for a detailed review of the studies conducted on customer experience in the hospitality industry see [14]). It is a complex construct with some operationalization issues still to be solved. The tourist experience reflects the customer's assessment of the multiple interactions with their accommodation, from pre-consumption, through consumption to post-consumption [17]. The tourist's experience is affected by each episode in the interaction with the hospitality industry (customer journey), and is the result of the co-creation that takes place from the interactions between customers, employees and other stakeholders [14-20]. In hospitality the customer experience derives not only from food, drink, reception, entertainment or facilities, but includes many other aspects such as websites, personal and digital interactions with employees and other customers, or transportation necessary to reach the destination.

Pine et al. [21] proposed four dimensions of experience: entertainment, education, aesthetics, and escapism, which have been applied in academic tourism research [22]. Another dimension used in tourism research is Csikszentmihalyi and Csikszentmihalyi's [23] flow experience, defined by Wu and Liang [20] as "a state determined by the balance of challenge and skills without any ingredient of anxiety, 
boredom or worry." The current prevailing view appears to be that the customer experience has five dimensions: cognitive (think), affective (feel), behavioral (act), sensory (sense) and social (relate) [17]. This proposal of dimensionality is gaining acceptance among researchers since it encompasses the two previous proposals [14].

In the field of hospitality, Cao et al. [24] consider that memorable experiences of food are structured in the five dimensions considered: sensory (sense), affective (feel), cognitive (think), physical (act) and relational (relate). But Cao et al. [24] regard it as a formative construct. In our view this should be reconsidered in light of what Jarvis et al. [25] deem to be the essential requirements for formative constructs. Following these authors, the tourist experience should be considered a reflective construct because: a) the five dimensions cannot be considered independent variables since any alteration in one of them affects the rest, b) changes in the construct cause changes in the indicators, $c$ ) the indicators share a common theme: the experiential experience, $d$ ) changes in one indicator are associated with the other indicators (they covary with each other), and e) the indicators have the same antecedents. We therefore propose the following hypothesis on the reflective nature of the construct:

$\mathrm{H}_{2}$ : The customer's experience with a tourist accommodation establishment is a reflective construct composed of five dimensions: cognitive, affective, behavioral, sensory, and social.

Satisfaction is the main outcome of the customer's experience [26,27]. Customer satisfaction is defined as the pleasant fulfillment of the customer's expectations [28]. Knowing whether or not customers' expectations have been met is a fundamental indicator in the hospitality industry [29]. Since satisfaction is the comparison between tourists' expectations and their actual experience, it can be assumed that customer experience will positively influence customer satisfaction [20]. Meyer and Schwager [30] suggest that satisfaction is the accumulation of diverse customer experiences, and is the net result of the sum of the positive experiences minus the negative ones. Lemon and Verhoef [17] make the same assumption in considering that satisfaction is a consequence of the customer's experience. Other research in the marketing field takes a similar line, establishing that a customer's assessment of their experience influences key outcomes such as satisfaction, loyalty, word of mouth (WOM) and customer lifetime value (CLV) [31,32]. In the area of branding, Brakus et al. [33] and Schmitt et al. [34] consider that the strength of the experience with a brand influences satisfaction and loyalty to the brand.

Some empirical research in the hospitality industry supports this hypothesis [29-35]. Several studies have shown that a memorable service experience in a hotel ensures the satisfaction of its guests [36-40]. Sathish and Venkatesakumar [41] concluded that the customer experience in a coffee outlet influences their satisfaction and loyalty. Wu and Liang [20] consider that customers can achieve their maximum desires through a flow experience, that is, the experience is an antecedent of satisfaction, demonstrating empirically that the experience of a rafting activity had a very positive influence on the tourist's satisfaction. Robinot and Giannelloni [42] conclude that hotels must analyze and provide not only the "basic" attributes necessary to avoid customer dissatisfaction but also the "extra" attributes, defined as the unexpected practices implemented in the hotel (such as clean and renewable energy), and are perceived as a positive experience that impact on customer satisfaction. The above arguments lead to our third hypothesis:

$\mathrm{H}_{3}$ : The customer's experience with a tourist accommodation establishment positively influences their satisfaction.

In summary, this paper proposes a model (Figure 1) in which the antecedent role of environmental sustainability in the hospitality industry perceived by tourists is analyzed in the customer experience $\left(\mathrm{H}_{1}\right)$, conceptualized as a second-order reflective construct composed of five fundamental dimensions: cognitive, affective, behavioral, sensory and social $\left(\mathrm{H}_{2}\right)$. In turn, this experience previous to, during, and after their stay in the accommodation will be decisive in generating greater tourist satisfaction $\left(\mathrm{H}_{3}\right)$. 


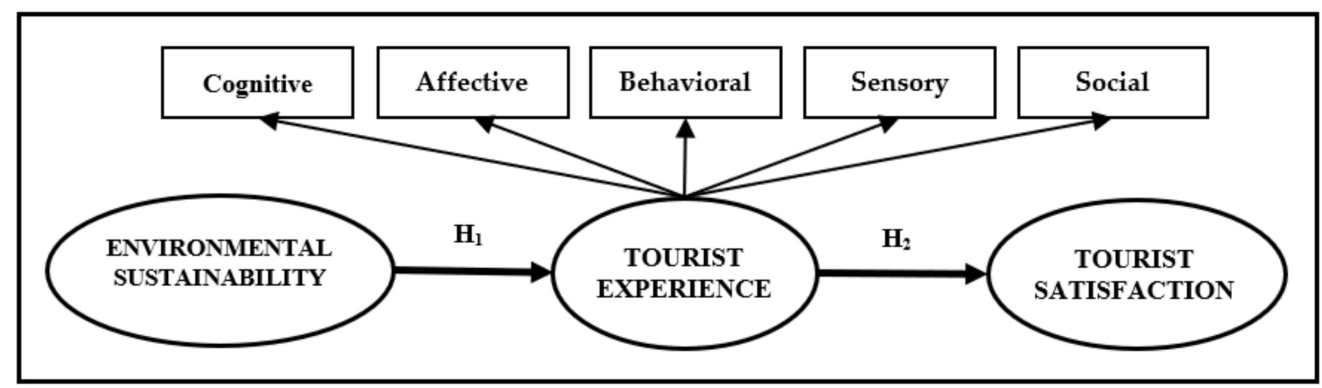

Figure 1. Model of effects.

\section{Method}

\subsection{Sample Selection and Data Collection}

Before beginning the fieldwork, and following the recommendations of Ye et al. [43] on design questionnaires to counter self-generated validity, careful attention was paid to the question order and the use of terminology and language that respondents would easily understand. Additionally, care was taken not to present the constructs in the order set out in our hypotheses (antecedents $\rightarrow$ mediating variables $\rightarrow$ consequences). Finally the questionnaire was translated from English into Spanish following Brislin's [44] back-translation method, which has been widely used in the specialized literature, in order to ensure the Spanish version was consistent with the original English version. Finally a pretest was carried out in the last quarter of 2018, involving five tourism industry experts and a group of 25 tourists.

Next, an electronic version was prepared in order to carry out the field work in January and February of 2019, from which 412 valid responses were obtained. Respondents, from the Valencian Region of Spain, were selected by means of a convenience sampling method. This is a non-probabilistic method and has the limitation of subjectivity in the selection of respondents. However, it is a widely used technique when randomization is impossible due to a very large population, or researchers' limited resources, time and support [45,46].

An analysis of the primary data provided the main characteristics of the sample for both the accommodation (Table 1) and the tourist profile (Table 2). The classification data show that $40 \%$ of the interviewees stayed in an urban hotel, whereas $24.3 \%$ stayed in a tourist apartment. The average stay was 4 days; the average age was 40 years; and two thirds of the interviewees were women. The level of income can be considered high since $66 \%$ earn more than $€ 1500$ per month. The majority of the sample was employed (56.8\%) or students (30.1\%). The most notable feature of the sample is that $98.1 \%$ of the interviewees have high school or higher education ( $80.6 \%$ have university studies and $17.5 \%$ completed high school). This sample profile must be taken into account when interpreting the results.

Table 1. Accommodation classification data.

\begin{tabular}{|c|c|c|c|c|c|c|c|c|}
\hline \multirow{4}{*}{$\begin{array}{c}\text { Country } \\
\begin{array}{c}\text { Accommodation } \\
\text { type }\end{array}\end{array}$} & \multicolumn{4}{|c|}{ Spain } & \multicolumn{4}{|c|}{ Other Countries } \\
\hline & \multicolumn{4}{|c|}{$132(64.1 \%)$} & \multicolumn{4}{|c|}{$74(35.9 \%)$} \\
\hline & $\begin{array}{l}\text { Urban } \\
\text { hotel }\end{array}$ & Hostel & $\begin{array}{l}\text { Sun and } \\
\text { sand hotel }\end{array}$ & Cottage & $\begin{array}{l}\text { Rural } \\
\text { hotel }\end{array}$ & $\begin{array}{c}\text { Tourist } \\
\text { apartment }\end{array}$ & Camping & Others \\
\hline & $39.8 \%$ & $7.8 \%$ & $6.3 \%$ & $9.7 \%$ & $9.2 \%$ & $24.3 \%$ & $1.5 \%$ & $1.4 \%$ \\
\hline \multirow{2}{*}{ Trip type } & \multicolumn{2}{|c|}{ Group trip } & \multicolumn{2}{|c|}{ Romantic trip } & \multicolumn{2}{|c|}{ Family trip } & \multicolumn{2}{|c|}{ Individual trip } \\
\hline & \multicolumn{2}{|c|}{$25.7 \%$} & \multicolumn{2}{|c|}{$32.5 \%$} & \multicolumn{2}{|c|}{$33.0 \%$} & \multicolumn{2}{|c|}{$8.7 \%$} \\
\hline \multirow{2}{*}{ Stay (mean: 4) } & \multicolumn{2}{|c|}{ 1-2 days } & \multicolumn{2}{|c|}{ 3-4 days } & \multicolumn{2}{|c|}{ 5-6 days } & \multicolumn{2}{|c|}{ More than 6 days } \\
\hline & $17.0 \%$ & & $5.1 \%$ & & & 21. & & \\
\hline
\end{tabular}


Table 2. Tourist classification data.

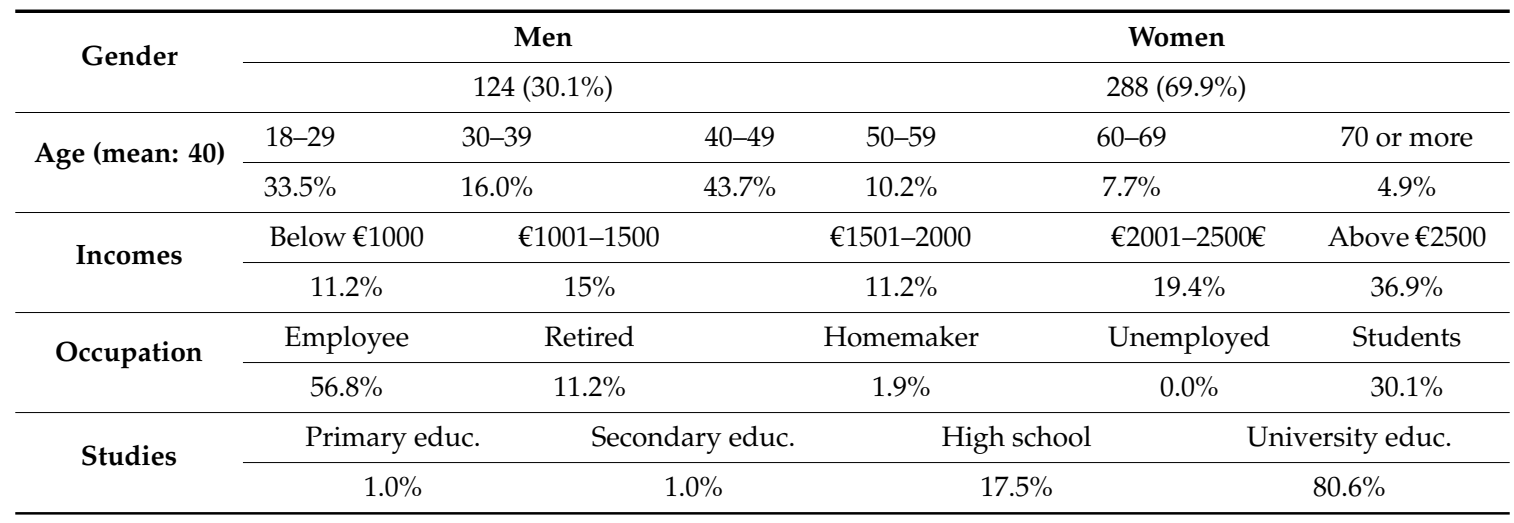

\subsection{Measurement Instruments}

All the scales used to measure the dimensions of the experience correspond exactly to their theoretical definitions. They had also all been devised by other authors and tested in previous studies, and adjusted in our study to adapt to the tourism accommodation context. The case was the same for the measurement of the constructs of environmental sustainability and tourist satisfaction. All the questionnaire items were valued on a 5-point Likert scale, where 1 represents totally disagree and 5, totally agree. Table 3 summarizes the sources of the measurement scales used in the study.

Table 3. Scales used.

\begin{tabular}{ccc}
\hline Variables & References & Items \\
\hline Environmental Sustainability & {$[47]$} & 5 \\
\hline Cognitive Experience & & 4 \\
Affective Experience & 5 \\
Behavioral Experience & {$[16,17,20,40,48]$} & 5 \\
Sensorial Experience & & 4 \\
Social Experience & & 4 \\
\hline Tourist Satisfaction & {$[49]$} & 4 \\
\hline
\end{tabular}

\subsection{Validity and Scale Reliability}

Confirmatory factor analysis (CFA) was performed using structural equation modeling (SEM) to refine the scales with version 6.1 of the EQS multivariate software package. The maximum likelihood approach was used to estimate the parameters.

Following Hair et al. [50], we considered a model development strategy. To improve initial models we conducted a refinement process which involved eliminating less relevant indicators based on the structures of the latent variables assumed for each construct. Jöreskog and Sorbom [51] recommend examining the estimation parameters. We eliminated the indicators that did not satisfy the strong convergence condition, that is, those having individual standardized coefficients $(\lambda)$ lower than 0.6 and an average standardized factor loading of less than 0.7 [50,52,53]. We then verified the compliance with the weak convergence condition [53] by analyzing the significance of the factor regression coefficients between indicators and their latent variables. To do this, we considered the Student $t$-value by imposing the maximum condition $(\mathrm{t}>2.58 ; \mathrm{P}=0.01)$. Following this process four indicators were removed: GOGN4, BEHA2, SENS2 and SOCI3 (see Table 4). 
Table 4. Summary of the results after factor, reliability, and validity analyses.

\begin{tabular}{|c|c|c|}
\hline Items & Factor Loads & t-Value \\
\hline \multicolumn{3}{|l|}{ Environmental Sustainability $(\alpha=0.894 ; \mathrm{CR}=0.90 ; \mathrm{AVE}=0.64)$} \\
\hline SUST1: The accommodation respected the environment. & 0.742 & $16.484^{* * *}$ \\
\hline SUST2: The accommodation showed a concern to reduce consumption of natural resources. & 0.872 & $22.991 * * *$ \\
\hline SUST3: Recycling was well managed. & 0.775 & $17.858^{* * *}$ \\
\hline SUST4: The accommodation establishment informed guests of its environmental practices. & 0.788 & $20.967^{* * *}$ \\
\hline SUST5: The accommodation consumed environmentally friendly renewable energy. & 0.810 & $21.155^{* * *}$ \\
\hline \multicolumn{3}{|l|}{ Tourist Experience $(\mathrm{CR}=0.95 ; \mathrm{AVE}=0.78)$} \\
\hline Cognitive experience ( $\alpha=0.808 ; C R=0.82 ; A V E=0.62)$ & 0.852 & $15.549 * * *$ \\
\hline COGN1: The experience with this accommodation establishment was enriching. & 0.913 & Fixed \\
\hline COGN2: The experience was instructive. & 0.792 & $18.860 * * *$ \\
\hline $\begin{array}{l}\text { COGN3: During the reservation and stay I didn't have to make an effort to focus on what I } \\
\text { was doing at each moment. }\end{array}$ & 0.620 & $9.758^{* * *}$ \\
\hline $\begin{array}{l}\text { COGN4: I overcame all the problems that occurred during the reservation and stay in the } \\
\text { accommodation. }\end{array}$ & \multicolumn{2}{|c|}{ Deleted } \\
\hline Affective experience $(\alpha=0.920 ; C R=0.92 ; A V E=0.70)$ & 0.970 & $14.548 * * *$ \\
\hline AFEC1: I enjoyed the experience in this accommodation. & 0.899 & Fixed \\
\hline AFEC2: The experience made me feel very good. & 0.875 & $21.701 * * *$ \\
\hline AFEC3: During my stay in the accommodation I forgot my daily problems. & 0.856 & $18.505^{* * *}$ \\
\hline AFEC4: At all times I felt that I was in control of what was happening. & 0.786 & $17.847^{* * *}$ \\
\hline AFEC5: It was a unique experience. & 0.752 & $15.726^{* * *}$ \\
\hline Behavioral experience $(\alpha=0.828 ; C R=0.80 ; A V E=0.58)$ & 0.637 & $8.963 * * *$ \\
\hline BEHA1: It was easy for me to make the decision to book this accommodation. & 0.715 & Fixed \\
\hline BEHA2: I did things spontaneously and automatically. & \multicolumn{2}{|c|}{ Deleted } \\
\hline BEHA3: I was sure at all times about what I wanted to do. & 0.752 & $16.060 * * *$ \\
\hline BEHA4: I was sure that I was doing everything right. & 0.812 & $17.164^{* * *}$ \\
\hline BEHA5: At all times I was aware of how well I was doing things. & 0.697 & $13.588^{* * *}$ \\
\hline Sensory experience ( $\alpha=0.934 ; C R=0.93 ; A V E=0.82)$ & 0.974 & $16.636^{* * *}$ \\
\hline SENS1: I liked the accommodation. & 0.906 & Fixed \\
\hline SENS2: During my stay, time seemed to alter. & \multicolumn{2}{|c|}{ Deleted } \\
\hline SENS3: I was very comfortable in the accommodation. & 0.855 & $13.141^{* * *}$ \\
\hline SENS4: I had a very good impression of the accommodation. & 0.955 & $25.365 * * *$ \\
\hline Social experience $(\alpha=0.818 ; C R=0.81 ; A V E=0.58)$ & 0.940 & $12.572 * * *$ \\
\hline SOCI1: I think the accommodation staff had a good impression of me. & 0.710 & Fixed \\
\hline SOCI2: The experience with the accommodation staff was pleasant. & 0.723 & $14.335^{* * *}$ \\
\hline SOCI3: The experience with the other guests in the accommodation was very good. & \multicolumn{2}{|c|}{ Deleted } \\
\hline SOCI4: My companions had a good impression of the accommodation. & 0.849 & $11.551 * * *$ \\
\hline \multicolumn{3}{|l|}{ Tourist Satisfaction $(\alpha=0.921 ; \mathrm{CR}=0.92 ; \mathrm{AVE}=0.75)$} \\
\hline SATI1: My expectations with the accommodation were met. & 0.889 & $15.208^{* * *}$ \\
\hline SATI2: I am satisfied with the service I received in the accommodation. & 0.854 & $14.036^{* * *}$ \\
\hline SATI3: The price I paid corresponded to the quality offered. & 0.780 & $13.443 * * *$ \\
\hline SATI4: In general, I am satisfied with the accommodation. & 0.942 & $17.299 * * *$ \\
\hline
\end{tabular}

Fit of the model: $\chi^{2} / \mathrm{df}=1060.239 / 286=3.706 ; \mathrm{IFI}=0.901 ; \mathrm{CFI}=0.900 ;$ SRMR $=0.067 ; \mathrm{RMSEA}=0.079$

Note: IR = individual reliability; $\mathrm{CR}=$ composite reliability; AVE = average variance extracted. ${ }^{* * *} p<0.001 ;{ }^{* *} p<$ $0.01 ; * p<0.05$

Finally, we monitored the evolution of the main model fit measurements as each indicator was eliminated. More specifically we used normed $\chi^{2}$ (Jöreskog and Sorbom [54]: values between 1 and 4 are considered acceptable), the incremental fit index (IFI) and the comparative fit index (CFI) (Hu and Bentler [55]: values above 0.90 are considered acceptable), the root mean square residual (RMR) (Hu and Bentler [55]: values below 0.08 are considered acceptable) and the root mean square error of approximation (RMSEA) (Browne and Cudeck [56]: values below of 0.08 show an acceptable fit).

Several verification tests were conducted to identify whether the above refinement tests negatively affected scale reliability (Table 4). For internal consistency, we tested Cronbach's alpha $(\alpha>0.7)$, construct composite reliability (CR $>0.7)$ and analysis of variance extracted (AVE $>0.5)$ [57-59].

Next, we analyzed the convergent and discriminant validity. To verify the convergent validity we returned to our initial confirmatory factor analysis and observed the estimated value and significance of the correlations between the scales' dimensions [60]. Convergent validity was confirmed by the relatively high and significant correlations. Table 5 reports the constructs' discriminant validity, 
confirmed through AVE [59]. When the square root of the AVE between each pair of factors is higher than the estimated correlation between those factors, as occurs here, discriminant validity is confirmed.

Table 5. Scale discriminant validity.

\begin{tabular}{ccccc}
\hline Factors & & $\mathbf{1}$ & $\mathbf{2}$ & $\mathbf{3}$ \\
\hline $\mathbf{1}$ & Environmental sustainability & 0.80 & & \\
$\mathbf{2}$ & Tourist experience & $0.48^{*}$ & 0.88 & \\
$\mathbf{3}$ & Tourist satisfaction & $0.43^{*}$ & $0.83^{*}$ & 0.87 \\
\hline
\end{tabular}

Note: Below the diagonal: correlation estimated between the factors. Diagonal: square root of AVE.* $p<0.01$.

\subsection{Complementary Data Analysis}

First, the variance inflation factor (VIF) among the latent variables in our proposed model verified the absence of any signs of multicollinearity. The results, with values between 1923 and 6227 (considerably lower than the maximum value of 10), suggested multicollinearity was not a problem in the study $[50,61]$. Second, we performed a t-test of independent means on the dimensions of the variables in the model, using the first 45 and last 45 respondents. The absence of non-response bias $[62,63]$ was confirmed as we found no significant differences between these respondents at the 0.05 level. Third, various ANOVA were run to confirm that sample characteristics do not affect the model constructs. The control variables were the accommodation and tourist classification factors displayed in Tables 1 and 2. The results revealed no significant differences in any of the analyses.

Additionally, we used the Harman test to assess the possibility of common method variance bias [64], which assumes that, if this bias exists, from a factor analysis one should expect a single factor to accumulate most of the covariance of independent and dependent variables [65]. As recommended by Podsakoff et al. [66], a factorial analysis was carried out on the 27 indicators resulting from the refining the process using principal component analysis [67] in which the unrotated factor solution is examined. The results of the factorial analysis revealed seven factors with eigenvalues greater than 1 . These factors explain $67.881 \%$ of the variance among the 27 items and the first of the factors accumulates $31.116 \%$. Hence, because several factors are identified, and the first factor does not accumulate most of the variance, a substantial part of the common method variance bias seems to be absent $[66,68,69]$.

\section{Analysis and Findings}

The next step is to test the hypotheses with the EQS multivariate software package version 6.1. Looking at each hypothesis proposed in the model and the results obtained after its estimations (Table 6), environmental sustainability emerges as a determining factor of the tourist's experience in their accommodation $\left(\mathrm{H}_{1}: \lambda=0.480, \mathrm{t}=7.182\right)$, understood from a multidimensional approach of five second-order factors (cognitive, affective, behavioral, sensory, and social). This experience will also have significant positive effects on tourist satisfaction in the accommodation context $\left(\mathrm{H}_{2}: \lambda=0.931\right.$, $\mathrm{t}=15.499$ ).

Table 6. Summary results of the structural model.

\begin{tabular}{cccccc}
\hline Hyp. & Path & Parameter & $t$-Value & Result & $\mathbf{R}^{2}$ \\
\hline $\mathrm{H}_{1}$ & Environmental sustainability $\rightarrow$ Tourist experience & 0.480 & $15.4999^{* * *}$ & Supported & 0.230 \\
$\mathrm{H}_{2}$ & Tourist experience $\rightarrow$ Tourist satisfaction & 0.931 & $7.182^{* * *}$ & Supported & 0.867 \\
\hline \multicolumn{5}{c}{ Fit of the model: $\chi^{2} / \mathrm{df}=991.303 / 286=3.466 ; \mathrm{IFI}=0.901 ; \mathrm{CFI}=0.900 ;$ SRMR $=0.056 ;$ RMSEA $=0.077$} \\
\hline \multicolumn{5}{c}{ Note: ${ }^{* * *}=p<0.001 ;{ }^{* *}=p<0.01 ;{ }^{*}=p<0.05}$.
\end{tabular}

These results were also supported by the review of the $\mathrm{R}^{2}$ obtained in testing the model. Following Hair et al.'s [70] rule of thumb that $R^{2}$ values of $0.75,0.50$ and 0.25 are substantial, moderate, or weak, 
respectively, we can see that the explanatory power of the model in its final dependent variable, tourist satisfaction, achieves a significant level $\left(R^{2}: 0.867\right)$.

In addition, we further analyze these effects by reviewing the indirect and total effects derived from the proposed model of relations [71]. Specifically, as shown in Table 7, the direct causal effect of environmental sustainability on tourist experience through its multidimensional consideration is supported by the positive and significant indirect effects of this variable on each of the aforementioned dimensions (cognitive: $0.408,4.923$, affective: $0.465,5.630$, behavioral: $0.305,3.802$, sensory: 0.467 , 5.267 , social: $0.453,4.684$ ). These analyses also provide information on the relative importance of each dimension's contribution to the tourist experience construct. Specifically, affective, sensory and social are the dimensions with the highest load (affective: 0.970, 17.204, sensory: 0.975, 13.908, social: $0.944,9.325)$, the cognitive dimension has an intermediate load $(0.851,11.613)$, while the behavioral dimension has the lowest load as compared to the experience construct $(0.636,6.311)$.

Table 7. Total and indirect effects derived from the results of the structural model.

\begin{tabular}{|c|c|c|c|c|}
\hline \multirow[t]{2}{*}{ Dependent Variable } & \multicolumn{2}{|c|}{$\begin{array}{c}\text { Effects from Environmental } \\
\text { Sustainability }\end{array}$} & \multicolumn{2}{|c|}{ Effects from Tourist Experience } \\
\hline & Parameter & t-Value & Parameter & t-Value \\
\hline Cognitive experience & 0.408 & $4.923 * * *$ & 0.851 & $11.613^{* * *}$ \\
\hline Affective experience & 0.465 & $5.630 * * *$ & 0.970 & $17.204^{* * *}$ \\
\hline Behavioral experience & 0.305 & $3.802 * * *$ & 0.636 & $6.311^{* * *}$ \\
\hline Sensory experience & 0.467 & $5.267 * * *$ & 0.975 & $13.908 * * *$ \\
\hline Social experience & 0.453 & $4.684^{* * *}$ & 0.944 & $9.325^{* * *}$ \\
\hline Tourist satisfaction & 0.446 & $5.491 * * *$ & 0.931 & $7.182 * * *$ \\
\hline Tourist experience & 0.480 & $15.499 * * *$ & & \\
\hline
\end{tabular}

\section{Conclusions}

\subsection{Theoretical Implications}

The study aimed to establish the relationship between customers' perceptions of the environmental practices in a tourist accommodation establishment and their experience and satisfaction. The results of testing the proposed model demonstrate that environmental sustainability has a direct and positive influence on the customer's experience in the accommodation and, indirectly, on their satisfaction.

The main conclusion is that the relationship between environmental sustainability and customer experience in the hospitality industry can be demonstrated. The literature holds that the history of customer experience must be sought in the various moments of truth in the customer journey (pre-consumption, consumption, and post-consumption) [14,17]. Although the theoretical framework allows environmental sustainability to be included in the list of antecedents, this relationship has not previously been explored in the literature. The study results show that investment of resources in environmental sustainability and the traveler's involvement in its implementation are appropriate strategies to directly improve the customer experience and, indirectly, their satisfaction. This sequence is a necessary and sufficient condition to obtain a positive recommendation in social media and specialized search engines as well as in offline channels that, when considered by other customers, can increase a company's income.

This conclusion has notable consequences in that it lends support to the strategy of implementing environmental sustainability in tourism $[8,18,19]$. In an environment as competitive as tourism, the hospitality industry cannot turn its back on a major megatrend like sustainability. Citizens are increasingly aware of the impact that humanity is having on the planet, with the result that when they travel as tourists they worry about their ecological footprint. To adapt to this reality, the hospitality industry must launch a long-term two-pronged strategy: 
First, the internal implementation of values and procedures linked to the saving of non-renewable resources (mainly water and energy) and the recycling of waste. This implies involving employees and creating an organizational culture favorable to sustainability [14,20].

Second, the necessary collaboration and involvement of the customer in co-creating sustainable tourism experiences. Saving resources such as water and energy, recycling waste, respect for biodiversity and limiting the emission of greenhouse gases are aspects in which the traveler can and wants to collaborate [2-7]. This implies that the procedures in which guests can collaborate and awareness of them should be promoted through on-site messages and advice from contact personnel.

A second relevant conclusion refers to the construct customer experience. Although this emerging concept is being studied in different sectors, empirical studies in the hospitality industry are virtually non-existent [14]. This paper validates a measurement scale based on the most accepted dimensionality of the construct: cognitive (think), affective (feel), behavioral (act), sensory (sense) and social (relate) [17]. Following the analysis of dimensionality, reliability and validity, the scale comprised 18 items, making it simple and practical to implement. The affective, sensory and social dimensions have the greatest influence on the formation of the customer's experience and satisfaction, although the other two (cognitive and behavioral) also have a significant impact. The items included in each dimension should guide the aspects to consider in managing the customer's experience, since by improving them customers will report more positive evaluations of the experience in social networks. Furthermore, in relation to the customer experience construct, the study has demonstrated its reflective nature, contrary to the proposal of Cao et al. [24].

In summary, this paper makes four contributions to the literature: a) a direct causal relationship between environmental sustainability and customer experience is established in the hospitality industry that had not previously been contrasted; $b$ ) an indirect relationship is established (through customer experience) between environmental sustainability and customer satisfaction, another aspect that had not previously been addressed in the literature; c) a customer experience measurement scale is validated in the hospitality industry based on the five dimensions proposed by Lemon and Verhoer [17]; and d) the reflective nature of the customer experience construct is demonstrated, contrary to findings to date in the literature [24].

\subsection{Practical/Managerial Implications}

The first implication is that the hospitality industry should place more emphasis on environmental aspects and on CSR programs [9]. Sustainability is now a megatrend that has repercussions across the entire world economy by increasing society's awareness of its impact on the planet. Environmental issues in the hospitality industry should include the management of climate change and greenhouse gas emissions, water management, waste management and recycling, environmentally responsible sourcing, biodiversity and protection and preservation of natural resources, the reduction of environmental impact, the creation of green construction standards for new hotels, and other ecology related aspects [2-7]. All of them should be urgently incorporated into hospitality industry strategies.

At a competitive level, firms should aim to be the first to achieve a competitive advantage in environmental sustainability since this places them in a privileged position in the customer's mind because of the association made between the attribute and the brand. In this sense, hospitality industry companies should view environmental sustainability as an opportunity and a strategic attribute with no clear owner, which can give a significant competitive advantage to companies that are the first to achieve this position $[8,19]$.

But from the point of view of marketing, it is not enough to incorporate sustainability into hotels' strategies. Although the hospitality industry is increasingly aware of environmental sustainability, especially due to pressure from tour operators and customers, there is much room for improvement in its communication of these environmental practices. Given their increasing relevance and their importance in the accommodation reservation decision and in evaluations of the hospitality industry experience, we recommend establishments improve their communication strategy on environmental 
practices. It should be noted that $80 \%$ of the travelers in the sample on which this study is based had university studies and a high income level. In order to capture this traveler profile, a communication strategy should be designed for both online and offline environments. In the online environment, accommodation establishments should prominently convey their environmental practices, thereby generating expectations among a public that is sensitive to sustainability, which would positively affect their purchase decision. In the offline environment managers should communicate the environmental practices carried out in the accommodation facilities and invite guests to collaborate in them, as this improves the visitor's experience. The key is to co-create sustainable tourism experiences, which implies involving tourists in environmental practices, as this will contribute to improving the customer experience and, in turn, lead to greater satisfaction.

Regarding the debate on the economic sense of investing in CSR in general, and environmental sustainability in particular, this paper offers evidence that such investment can increase profits. Although the empirical results do not allow us to directly relate environmental sustainability with economic benefits or income, we can infer from the high percentage of variance explained by satisfaction (0.867) that the accommodation firm's income will improve as a result of positive online and offline comments from guests. Although environmental sustainability does not explain a particularly high percentage of variance of customer experience (0.230), the relationship is clearly significant and, indirectly, helps to generate visitor satisfaction.

The conclusions of this paper also suggest a line of action for online booking search engines such as Booking and Expedia, among others, or the accommodation's own reservation websites, namely that environmental sustainability should be included as a criterion for travelers' evaluations of the accommodation. Along with services, quality, staff attention and others, we recommend including environmental sustainability since it is an aspect that significantly impacts the visitor's experience. This will allow other travelers with an awareness of sustainability to identify accommodation that best suits their wishes and needs. It may even be possible to infer that information about environmental sustainability could justify an increase in the price since it is an attribute that adds value to the offer and that travelers are willing to pay for.

\subsection{Limitations and Future Research}

The study is not without certain limitations that must be taken into account when evaluating our conclusions. These limitations open up possible future lines of research.

The main methodological limitation is the sample, which was a convenience sample and is therefore limited in terms of randomness and representativeness. This is a common exception in surveys conducted online through social media. Similarly, the study focuses on Spanish tourists. Given that the sample represents a very specific segment of the population, the conclusions should not be generalized. New research on this topic is therefore needed to guarantee the random and stratified character of the sample analyzed in different cultural and international contexts in order to generalize the results.

In fact, a greater balance in the strata would allow for new comparative multi-group analyses based on sociodemographic variables such as age. Thus, for example, it is reasonable to assume that millennials will behave differently to seniors, which could have important repercussions for marketing strategies.

A second limitation concerns the use of cross-sectional data, which prevents causal inferences from being drawn. Considering this limitation, future research should study the relationships proposed here using longitudinal data and combining the positivist and interpretative method, as in the case of the ethnographic or phenomenological method [72]. Taking Coviello and Jones [72] as a reference, the reconciliation of positivist and interpretative methodologies would extend knowledge about tourists' behavior in their experience of accommodation. Indeed, a longitudinal approach would help to clarify the specific influence of the influential factors in each stage of the process experienced by the tourist (before, during and after enjoyment) as Lemon and Verhoef [17] point out. 
Our model represents a specific theoretical reference from which to consider new antecedent factors and consequences of the tourist experience valued recently in the specialized literature. Future work should help to identify new factors that depend on other agents contributing to generate experience (associated with the destination, destination partners, the tourist, or other external agents) before, during, and after the visit to the destination [17]. In this context, it would be of great interest to complete the analysis of these background factors by assessing the possible interdependencies between them. On the other hand, in relation to the consequential factors, new variables associated with the quality of the relationship with tourists could be included, such as engagement, loyalty, emotions and, especially, the advocacy effect [73-75]. Regarding this last factor, we conjecture that the information from and influence of WOM could have a major influence in the emotional bond between the destination (in its broad sense) and the tourist. This influence may be even greater in the online context, given the credibility that some consumer segments attribute to the opinions of others.

Additionally, in light of the relentless technological revolution, a relevant line of research arising from the study lies in the focus on the online environment. This is a fascinating landscape from the co-creation perspective, but it raises new challenges for experiential marketing.

Finally, we must bear in mind that this paper focuses on the tourist's perception. This vision could be complemented with new analytical approaches examining the business plan. In this way, a direct perception could be used to analyze how the different practices implemented internally by tourism sector managers influence their financial and non-financial results.

These two approaches, focusing on the tourist and on the company, could also be combined through methodologies associated with the construction of dyads between the two agents.

Author Contributions: Conceptualization, M.Á.M., D.M., M.E. and R.M.R.; Methodology, M.Á.M. and D.M.; Software, D.M.; Validation, D.M.; Formal Analysis, D.M.; Investigation, M.E. and R.M.R.; Resources, M.Á.M., M.E. and R.M.R.; Writing—Original Draft Preparation, M.Á.M. and D.M.; Writing—Review \& Editing, R.M.R.; Visualization, M.E. and R.M.R.; Supervision, M.Á.M.

Funding: This research received no external funding.

Conflicts of Interest: There is no conflict of interest.

\section{References}

1. Jones, P.; Hillier, D.; Comfort, D. Sustainability in the hospitality industry: Some personal reflections on corporate challenges and research agendas. Int. J. Contemp. Hosp. M. 2016, 28, 36-67. [CrossRef]

2. Lim, W.M. Creativity and sustainability in hospitality and tourism. Tour. Manag. Perspect. 2016, 18, $161-167$. [CrossRef]

3. Rodríguez-Antón, J.M.; Alonso-Almeida, M.M.; Celemín, M.S.; Rubio, L. Use of different sustainability management systems in the hospitality industry. The case of Spanish hotels. J. Clean. Prod. 2012, 22, 76-84.

4. Dos Santos, R.A.; Méxas, M.P.; Meiriño, M.J. Sustainability and hotel business: Criteria for holistic, integrated and participative development. J. Clean. Prod. 2017, 142, 217-224. [CrossRef]

5. Martínez, P.; Pérez, A.; Del Bosque, I.R. Exploring the role of CSR in the organizational identity of hospitality companies: A case from the Spanish tourism industry. J. Bus. Ethics 2014, 124, 47-66.

6. United Nations World Tourism Organization-UNWTO. Panorama OMT del Turismo Internacional. 2018. Available online: http://www.unwto.org (accessed on 20 February 2019).

7. Niñerola, A.; Sánchez-Rebull, M.V.; Hernández-Lara, A.B. Tourism Research on Sustainability: A Bibliometric Analysis. Sustainability 2019, 11, 1377.

8. Berezana, O.; Raaba, C.; Yoo, M.; Lovea, C. Sustainable hotel practices and nationality: The impact on guest satisfaction and guest intention to retorn. Int. J. Hosp. Manag. 2013, 34, 227-233. [CrossRef]

9. Suárez-Cebador, M.; Rubio-Romero, J.C.; Pinto-Contreiras, J.; Gemar, G. A model to measure sustainable development in the hotel industry: A comparative study. Corp. Soc. Resp. Env. Ma. 2018, 25, 722-732. [CrossRef]

10. Friedman, M. The Social Responsibility of Business Is to Increase Its Profits; Corporate Ethics and Corporate Governance; Springer: Berlin/Heidelberg, Germany, 2007; pp. 173-178. 
11. Gémar, G.; Espinar, D. Communication about corporate social responsibility practices and return on equity. R. E. F. 2015, 581, 7-15. [CrossRef]

12. Heo, C.Y.; Lee, S. Application of revenue management practices to the theme park industry. Int. J. Hosp. Manag. 2009, 28, 446-453. [CrossRef]

13. Teixeira, J.; Patrício, L.; Nunes, N.J.; Nóbrega, L.; Fisk, R.P.; Constantine, L. Customer experience modeling: From customer experience to service design. J. Serv. Manag. Res. 2012, 23, 362-376. [CrossRef]

14. Kandampully, J.; Zhang, T.; Jaakkola, E. Customer experience management in hospitality: A literature synthesis, new understanding and research agenda. Int. J. Contemp. Hosp. M. 2018, 30, 21-56. [CrossRef]

15. Chen, C.F.; Huang, W.J.; Petrick, J.F. Holiday recovery experiences, tourism satisfaction and life satisfaction. Is there a relationship? Tourism Manage. 2016, 53, 140-147. [CrossRef]

16. Pijs, R.; Groen, B.H.; Galetzka, M.; Pruyn, A.T. Measuring the experience of hospitality: Scale development and validation. Int. J. Hosp. Manag. 2017, 67, 125-133. [CrossRef]

17. Lemon, K.N.; Verhoef, P.C. Understanding customer experience throughout the customer journey. J. Mark. 2016, 80, 69-96. [CrossRef]

18. Lee, J.; Hsu, L.; Han, H.; Kim, Y. Understanding how consumers view green hotels: How a hotel's green image can influence behavioural intentions. J. Sustain. Tour. 2010, 18, 901-914. [CrossRef]

19. Benavides-Velasco, C.A.; Quintana-García, C.; Marchante-Lara, M. Total quality management, corporate social responsibility and performance in the hotel industry. Int. J. Hosp. Manag. 2014, 41, 77-87. [CrossRef]

20. Wu, C.H.J.; Linang, R.D. The relationship between white-water rafting experience formation and customer reaction: A flow theory perspective. Tourism Manage. 2011, 32, 317-325. [CrossRef]

21. Pine, B.J.; Pine, J.; Gilmore, J.H. The Experience Economy: Work Is Theatre E Every Business a Stage; Harvard Business Press: Brighton, MA, USA, 1999.

22. Oh, H.; Fiore, A.M.; Jeoung, M. Measuring experience economy concepts: Tourism applications. J. Travel Res. 2007, 46, 119-132. [CrossRef]

23. Csikszentmihalyi, M.; Csikszentmihalyi, I. Beyond Boredom and Anxiety; Jossey-Bass: San Francisco, CA, USA, 1975.

24. Cao, Y.; Li, X.; Di Pietro, R.; So, K.K.F. The creation of memorable dining experiences: Formative index construction. Int. J. Hosp. Manag. 2018. [CrossRef]

25. Jarvis, C.B.; MacKenzie, S.B.; Podsakoff, P.M. A critical review of construct indicators and measurement model misspecification in marketing and consumer research. J. Consum. Res. 2003, 30, 199-218. [CrossRef]

26. Chahal, H.; Dutta, K. Measurement and impact of customer experience in banking sector. Decision 2015, 4, 57-70. [CrossRef]

27. Klaus, P.; Gorgoglione, M.; Buonamassa, D.; Panniello, U.; Nguyen, B. Are you providing the "right" customer experience? The case of Banca Popolare di Bari. Int. J. Bank Mark. 2013, 31, 506-528. [CrossRef]

28. Oliver, R.L. A cognitive model of the antecedents and consequences of satisfaction decisions. J. Mark. Res. 1980, 17, 460-469. [CrossRef]

29. Ryan, C. Tourist experiences, phenomenographic analysis, post-positivism and neural network software. Int. J. Tour. Res. 2000, 2, 119-131. [CrossRef]

30. Meyer, C.; Schwager, A. Understanding customer experience. Harvard Bus. Rev. 2007, 85, 116-126.

31. Bolton., R.N.; Lemon, K.N.; Bramlett, M.D. The Effect of Service Experiences over Time on a Supplier's Retention of Business Customers. Manage. Sci. 2004, 52, 1811-1823. [CrossRef]

32. Verhoef, P.C. Understanding the effect of customer relationship management efforts on customer retention and customer share development. J. Mark. 2003, 67, 30-45. [CrossRef]

33. Brakus, J.J.; Schmitt, B.H.; Zarantonello, L. Brand experience: What is it? How is it measured? Does it affect loyalty? J. Mark. 2009, 73, 52-68. [CrossRef]

34. Schmitt, B.; Brakus, J.J.; Zarantonello, L. From experiential psychology to consumer experience. J. Consum. Psychol. 2015, 25, 166-171. [CrossRef]

35. Vittersø, J.; Vorkinn, M.; Vistad, O.I.; Vaagland, J. Tourist experiences and attractions. Ann. Tourism Res. 2000, 27, 432-450. [CrossRef]

36. Slatten, T.; Krogh, C.; Connolley, S. Make it memorable: Customer experiences in winter amusement parks. Int. J. Cult. Tourism Hospit. Res. 2011, 5, 80-91. [CrossRef]

37. Olsson, L.; Friman, M.; Pareigis, J.; Edvardsson, B. Measuring service experience: Applying the satisfaction with travel scale in public transport. J. Retailing Consum. Serv. 2012, 19, 413-418. [CrossRef] 
38. Hou, M.; Wu, X.; Hu, Z. Personnel Service, Consumption Emotion, and Patronage Intention in Department Stores. J. Int. Bus. Res. 2013, 6, 6-21. [CrossRef]

39. Dölarslan, E.S. Assessing the effects of satisfaction and value on customer loyalty behaviors in service environments: High-speed railway in Turkey as a case study. Manage. Res. Rev. 2014, 37, 706-727. [CrossRef]

40. Ali, F.; Amin, M.; Cobanoglu, C. An integrated model of service experience, emotions, satisfaction, and price acceptance: An empirical analysis in the Chinese hospitality industry. J. Hospit. Market. Manag. 2016, 25, 449-475. [CrossRef]

41. Sathish, A.S.; Venkatesakumar, R. Coffee Experience and Drivers of Satisfaction, Loyalty in a Coffee outlet-With special reference to "café coffee day". Contemp. Manag. Res. 2011, 5, 1-13.

42. Robinot, E.; Giannelloni, J.L. Do hotels' "green" attributes contribute to customer satisfaction? J. Serv. Mark. 2010, 24, 157-169. [CrossRef]

43. Ye, J.; Marinova, D.; Singh, J. Strategic Change Implementation and Performance Loss in the Front Lines. J. Mark. 2007, 71, 156-171. [CrossRef]

44. Brislin, R.W. Back translation for the cross-cultural research. J. Cross-Cult. Psychol. 1970, 1, $185-216$. [CrossRef]

45. Mackey, A.; Gass, S. Second Language Research: Methodology and Design; Lawrence Erlbaum Associates, Inc.: New Jersey, NJ, USA, 2005.

46. Etikan, I.; Musa, S.A.; Alkassim, R.S. Comparison of Convenience Sampling and Purposive Sampling. A. J. T. A. S. 2016, 5, 1-4. [CrossRef]

47. Martínez, R.P.; Pérez, A.; del Bosque, I.R. Measuring corporate social responsibility in tourism: Development and validation of an efficient measurement scale in the hospitality industry. J. Travel Tour. Mark. 2013, 30, 365-385. [CrossRef]

48. Ren, L.; Qiu, H.; Wang, P.; Lin, P.M.C. Exploring customer experiencie with budget hotels: Dimensionality and satisfaction. Int. J. Hosp. Manag. 2016, 52, 13-23. [CrossRef]

49. Bloemer, J.M.M.; Odekerken-Schröder, G.J. Store satisfaction and store-related explained by customer-and store related factors. J. C. S. D. C. B. 2002, 15, 68-80.

50. Hair, J.F.; Black, W.C.; Babin, B.J.; Anderson, R.E. Multivariate Data Analysis; Prentice Hall: Upper Saddle River, NJ, USA, 2010.

51. Jöreskog, K.G.; Sorbom, D. LISREL 8: Structural Equation Modeling with the Simplis Command Language; Scientific Software International Inc.: Chicago, IL, USA, 1993.

52. Bagozzi, R.P.; Youjae, Y. On the Evaluation of Structural Equation Models. J. Acad. Mark. Sci. 1988, 16, 74-94. [CrossRef]

53. Steenkamp, J.B.E.M.; van Trijp, H.C.M. The use of lisrel in validating marketing constructs. Int. J. Res. Mark. 1991, 8, 283-299. [CrossRef]

54. Jöreskog, K. A general approach to confirmatory maximum likelihood factor analysis. Psychometrika 1969, 34, 183-202.

55. Hu, L.; Bentler, P.M. Cutoff criteria for fit indices in covariance structure analysis. Struct. Equ. Modeling 1999, 6, 1-55. [CrossRef]

56. Browne, M.W.; Cudeck, R. Alternative ways of assessing model fit. In Testing Structural Equation Models; Bollen, K.A., Long, J.S., Eds.; CA Sage: Beverly Hills, CA, USA, 1993; pp. 136-162.

57. Churchill, G.A. A Paradigm for Developing Better Measures of Marketing Constructs. J. Mark. Res. 1979, 16, 64-73. [CrossRef]

58. Nunnally, J.C. Psychometric Theory; McGraw Hill: New York, NY, USA, 1967.

59. Fornell, C.; Larcker, D.F. Structural Equation Models with Unobservable Variables and Measurement Error: Algebra and Statistics. J. Mark. Res. 1981, 18, 39-50. [CrossRef]

60. Monferrer, D.; Blesa, A.; Ripollés, M. Catching dynamic capabilities through market-oriented networks. Eur. J. Int. Manag. 2015, 9, 384-408. [CrossRef]

61. Kutner, M.H.; Nachtsheim, C.J.; Neter, J. Applied Linear Regression Models; McGraw-Hill Irwin: Chicago, IL, USA, 1996.

62. Armstrong, J.S.; Overton, T.S. Estimating non-response bias in mail surveys. J. Mark. Res. 1977, 16, $396-402$. [CrossRef]

63. Collier, J.E.; Bienstock, C.C. An analysis of how non-response error is assessed in academic marketing research. Mark. Theory 2007, 7, 163-183. [CrossRef] 
64. Harman, H.H. Modern Factor Analysis; The University of Chicago Press: Chicago, IL, USA, 1976.

65. Podsakoff, P.M.; Organ, D.W. Self-reports in organizational research: Problems and prospects. J. Manag. 1986, 12, 531-544. [CrossRef]

66. Podsakoff, P.M.; MacKenzie, S.B.; Lee, J.Y.; Podsakoff, N.P. Common method biases in behavioral research: A critical review of the literature and recommended remedies. J. Appl. Psychol. 2003, 88, 879-903. [CrossRef]

67. Velicer, W.F.; Jackson, D.N. Component analysis versus common factor analysis: Some further observations. Multivar. Behav. Res. 1990, 25, 97-114. [CrossRef] [PubMed]

68. Friedrich, T.L.; Byrne, C.L.; Mumford, M.D. Methodological and theoretical considerations in survey research. Leadersh. Q. 2009, 20, 57-60. [CrossRef]

69. MacKenzie, S.B.; Podsakoff, P.M. Common Method Bias in Marketing: Causes, Mechanisms, and Procedural Remedies. J. Retailing 2012, 88, 542-555. [CrossRef]

70. Hair, J.F.; Ringle, C.M.; Sarstedt, M. PLS-SEM: Indeed a silver bullet. J. Mark. Theor. Pract. 2011, 19, $139-151$. [CrossRef]

71. Bentler, P.M. EQS 6 Structural Equations Program Manual; Multivariate Software, Inc.: Encino, CA, USA, 2006.

72. Coviello, N.E.; Jones, M.V. Methodological issues in international entrepreneurship research. J. Bus. Venturing 2004, 19, 485-508. [CrossRef]

73. Lin, C.H.; Kuo, B.Z.L. The behavioral consequences of tourist experience. Tour. Manag. Perspect. 2016, 18, 84-91. [CrossRef]

74. Antón, C.; Camarero, C.; Laguna-García, M. Towards a new approach of destination loyalty drivers: Satisfaction, visit intensity and tourist motivations. Curr. Issues Tour. 2017, 20, 238-260. [CrossRef]

75. Sangpikul, A. The effects of travel experience dimensions on tourist satisfaction and destination loyalty: The case of an island destination. Int. J. Cult. Tourism Hospit. Res. 2018, 12, 106-123. [CrossRef]

(C) 2019 by the authors. Licensee MDPI, Basel, Switzerland. This article is an open access article distributed under the terms and conditions of the Creative Commons Attribution (CC BY) license (http://creativecommons.org/licenses/by/4.0/). 